\title{
Service quality in Islamic banks: The role of PAKSERV model, customer satisfaction and customer loyalty
}

\author{
Feras M.I. Alnaser ${ }^{a^{*}}$, Mazuri Abd Ghani ${ }^{\mathrm{b}}$ and Samar Rahi ${ }^{\mathrm{b}}$
}

${ }^{a}$ Ph.D Scholar, Universiti Sultan Zainal Abidin, Terengganu, Malaysia

${ }^{b}$ Universiti Sultan Zainal Abidin, Terengganu, Malaysia

\begin{tabular}{l}
\hline C H R O N I C L E \\
\hline Article history: \\
Received July 17, 2017 \\
Received in revised format \\
August 112017 \\
Accepted August 252017 \\
Available online \\
August 252017 \\
\hline Keywords: \\
PAKSERV \\
Cultural context \\
Customer satisfaction \\
Customer loyalty \\
Structural equation modeling \\
(SEM)
\end{tabular}

\section{A B S T R A C T}

\begin{abstract}
In service oriented industry, it is very difficult to set a standard rule to satisfy customers. As customer awareness increases on the service offered by banks, expectation from services quality increases too. Quality of a service in banking industry plays an essential role in measuring the performance of banks. Thus, the present study examines the PAKSERV model to measure customer satisfaction and customer loyalty of Islamic Banks in Palestine. A survey method was adopted where data was collected from 482 respondents through structured questionnaire. Structural equation model (SEM) was applied to check the hypothesis relationship between proposed constructs. Statistical finding revealed that PAKSERV model had significant impact on customer satisfaction and customer loyalty in Islamic banks of Palestine. Results also revealed that in cultural context PAKSERV model was the most appropriate scale and had predictive power of service quality in banking industry of Palestine. The findings of this study will be helpful for managers and policy makers to improve the service quality in Islamic banks of Palestine.
\end{abstract}

\section{Introduction}

The rapid development and competition of services has made it important for companies to measure service quality (Brown \& Bitner, 2006). Islamic banking is one of the most important services segment in which some traditional rules of marketing may not apply. Islamic banking implies that this segment must appeal to Muslim customers who use Islamic banks to fulfil their religious obligation (Amin et al., 2013). Furthermore, for Muslims modern Islamic banks is an obvious choice as they simultaneously invest their income and fulfil the religious obligation (Amin et al., 2013). Islamic banking in Arab region is the most popular banking and growing rapidly. Also in Palestine region Islamic banking has been seen most influential banking and growing sharply. Thus, in order to measure service quality of Islamic banks, PAKSERV model was incorporated in this study. Palestine region is dominated with

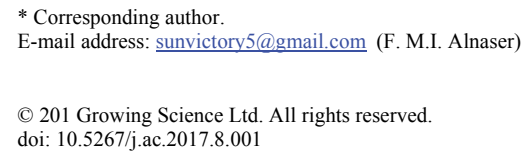


strong cultural influence thus PAKSERV model was supposed to be the best for service quality measurement.

Service companies that operate in a variety of cultural context have found that the most popular generic measure of service quality i.e. SERVQUAL is less applicable and not meaningful outside of developing countries (Malhotra et al., 2005). Thus, in developing countries SERVQUAL model has been found unsatisfactory especially in cultural oriented countries (Laroche, Ueltschy, Abe, Cleveland, \& Yannopoulos, 2004). Culture has strong influence on customers' expectations. According to Malhotra et al. (2005) explained that services are delivered often depends on appropriate expression of culturally acceptable emotions (sincerity) and behaviours (formality and personalisation). For instance in many Muslim countries, smiling at customer during the service experience was considered unacceptable emotion (Ashforth \& Humphrey, 1993). Arab region is also one of the sensitive region where culture strongly impact on people deeds. As service meeting is different between countries, international managers must gain an understanding of different dimensions of service quality according to culture emphasize (Malhotra et al., 2005).

Besides, the measurement of service quality dimensions in cultural context, this study also check the path from customer satisfaction to customer loyalty (Kitapci et al., 2013). Islamic financial service organisations worldwide are facing serious marketing challenges such as diverse customer base with varied expectations. All these challenges have raise the marketing competition in Islamic banks to attract and retain customers (Kamarulzaman \& Madun, 2013). Thus, this study is measured the customer satisfaction and their loyalty towards Islamic banks in Palestine.

\section{Literature Review}

\subsection{Service Quality}

In service marketing literature SERVQUAL model was extended by Avkiran (1999) with BANKSERV model. According to Zeithaml, Berry, and Parasuraman (1996) the measurement and achievement of service quality has been advantageous for the firm due to several reasons such as lower cost, customer loyalty and increased market share. The BANKSERV model obtained four dimensions of service quality include: staff conduct, credibility, communication and access to teller services (Avkiran, 1999). This model was further refined by Bahia and Nantel (2000) with new BSQ model. The newly proposed model banking service quality (BSQ) was comprised in six dimensions (Bahia \& Nantel, 2000). The most recent study with SERVQUAL model was examined in India where Vanparia and Patel (2013) compared SERVQUAL, BSQ and BANKQUAL models and found that BANKQUAL model has the highest reliability in Indian banks. SERVQUAL was extended by Raajpoot (2004) where researcher proposed new model PAKSERVE after dropping two main dimensions of SERVQUAL. Raajpoot (2004) explained that tangibility, reliability and assurance were the most important dimension of SERVQUAL model. Raajpoot (2004) proposed service quality model that was totally developed in cultural context and found that in non-western countries PAKSERV model is the most suitable model to measure service quality.

\subsection{PAKSERV Model}

The revolutionary SERVQUAL model was developed by Parasuraman, Zeithaml, and Berry (1985). Initially the model was comprised with 10 dimensions, which further reduce to five dimensions. There are five core dimension of SERVQUAL model, namely tangibility, reliability, assurance, empathy and responsiveness. The key definition of these five dimensions as follows,

1. Tangibility is seen as appearance of physical facilities, equipment, personnel, and communication material (Parasuraman et al., 1985). 
2. Reliability is defined as the ability to perform the promised service dependably and accurately (Parasuraman et al., 1985).

3. Assurance is defined as the courtesy of employees and their ability to inspire trust and confidence (Parasuraman et al., 1985).

4. Responsiveness is defined as employee willingness to guide customers and look fully engaged while service is performed (Parasuraman et al., 1985).

5. Empathy is defined as employees pay full attention to customers during service delivery (Parasuraman et al., 1985)

In developing countries SERVQUAL model has been found unsatisfactory especially in cultural oriented countries (Laroche et al., 2004). Thus, Raajpoot (2004) adapted and extended SERVQUAL model in cultural perspective named PAKSERV. The newly developed PAKSERV model comprised six dimensions and 24 items to measure the service quality in Pakistani cultural context. The PAKSERV model confirmed the three dimensions of SERVQUAL model however replaced responsiveness and empathy with three new dimensions described as follows.

1. Sincerity; where consumer's evaluation of the genuineness of the service personnel.

2. Formality; where consumer's evaluation of social distance, form of address and ritual.

3. Personalization; where consumer's evaluation of customization and individualized attention.

PAKSERV model was verified that cultural dimensions of service quality are important when customers evaluated encounters (Raajpoot, 2004). PAKSERVE model was also confirmed in African cultural context where all the six dimensions of PAKSERV model was found significant to measure service quality in banking sector (Graham Saunders, 2008). Thus, by following PAKSERV model the following hypotheses are proposed;

H1: Tangibility is significantly influence on customer satisfaction

$\mathrm{H} 2$ : Reliability is significantly influence on customer satisfaction

H3: Assurance is significantly influence on customer satisfaction

H4: Sincerity is significantly influence on customer satisfaction

H5: Personalization is significantly influence on customer satisfaction

H6: Formality is significantly influence on customer satisfaction

\subsection{Customer Satisfaction and Loyalty}

Customer satisfaction is defined as process of service to complete and fulfil the customer's expectation. Similarly Oliver (1980) explained customer satisfaction to complete fulfilment of one's expectations. Customer satisfaction is an antecedent of customer loyalty (Rahi, 2016; Rahi \& Ghani, 2016; Rahi et al., 2017). According to Baumann et al. (2011), loyalty is an attitude as well as specific behavior. Customer loyalty has been an important element to increase firm profitability (Oliver, 1997). Regardless of the service quality measurement, it is evident that service quality influences customers' perceived value, satisfaction, and loyalty (Marković et al., 2015). The behavioural loyalty reflects customer's positive response to purchase a particular product or service (Amin et al., 2013; Rahi, 2015; Rahi, 2016; Rahi \& Ghani, 2016). Customers who are loyal with banks spend much more than other customers (Amin et al., 2013). It has confirmed that marketing activities linked to the customer satisfaction and sometime it linked with customer buying behaviour. According to East (1997) if customers are satisfied with product or services then the chances of buying would increase. Taylor and Baker (1994) explained that intention to repeatedly purchase the product rely heavily on customer satisfaction. Thus, the following hypothesis is generated;

H7: Customer satisfaction is significantly influence on customer loyalty 


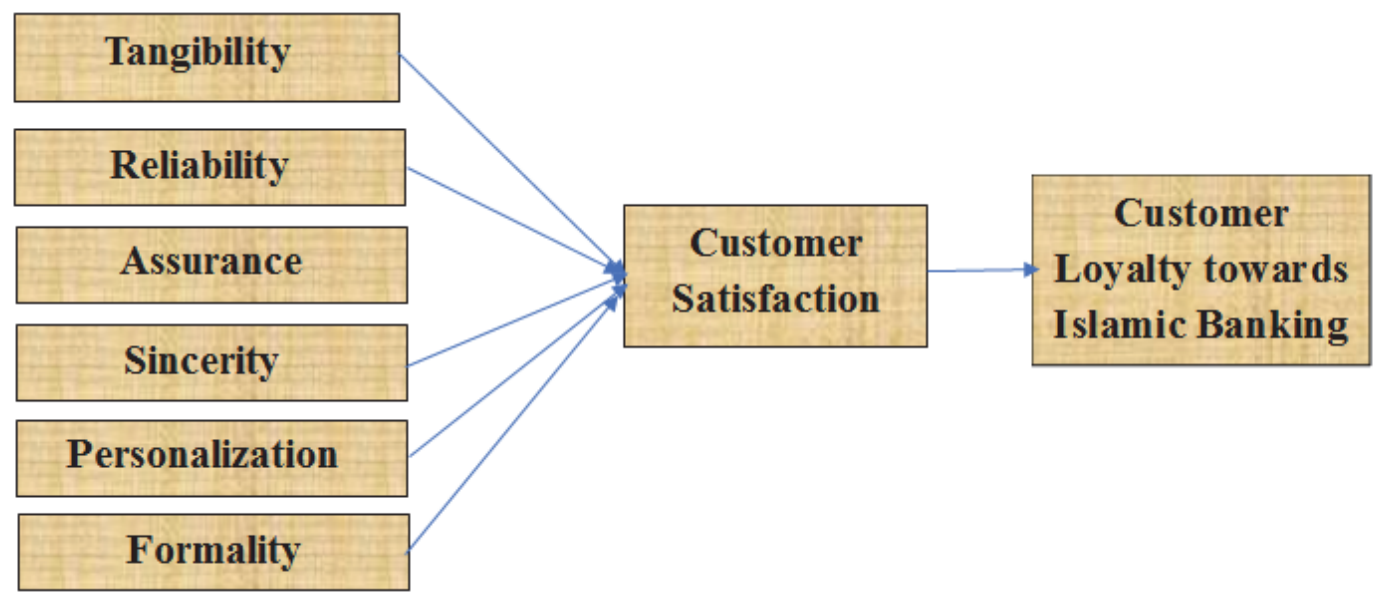

\section{Methodology}

Fig. 1. Theoretical Framework

\subsection{Survey Design and Sampling}

As this study concern service quality in Islamic banks of Palestine, the sample consists of one of Islamic bank customers in the city of Ramallah, Palestine. Convenience sampling method was used in this study. Data was collected through a structured questionnaire. Convenience sampling defined as a process of data collection from population that is close at hand and easily accessible to researcher (Rahi, 2017). Furthermore, convenience sampling allows researcher to complete interviews or get responses in a cost effective way Hair (2003). In order to collect the data researcher personally visited the Arab Islamic Bank and requested to Islamic Bank customers to fill the questionnaire. Gpower software was used to calculate the minimum sample size required. Hence, a set of 600 structured questionnaires were distributed out of 482 useable responses were received from customers of Islamic Banks.

\subsection{Instrument Development}

A questionnaire was developed for the survey using constructs and items from literature. The survey had two parts. The first part comprised on dimensions of PAKSERV model, customer satisfaction and customer loyalty. The six dimensions of PAKSERV model had 20 items and adapted from previous developed scale by (Raajpoot, 2004). Customer satisfaction consisted of 3 items adapted from Sayani (2015) . Lastly, 3 items of customer loyalty adopted from Rahi et al. (2017). Each item was measured on a seven-point Likert scale, ranging from 1 (totally disagree) to 7 (totally agree). The second part comprised of respondent demographics characteristics such as age, gender and education.

\subsection{Respondent's Profile}

The demographic of the respondents are tabulated in Table 1. The demographics of the sample selected to achieve the purpose of this study. Males were (52.4\%) slightly more than females $(47.6 \%)$. The age of the respondents $34.0 \%$ is for less than 20 years old, $36.4 \%$ that counts at age between 21 to 30 years, $19.2 \%$ for 31 to $40 y e a r s$ and $10.4 \%$ respondents aged 41 to 50 . Furthermore, Table 1 also depicted that education of the respondents $3.0 \%$ respondents were having high school education, $8.2 \%$ from those who has diploma, $11.6 \%$ respondents who has bachelor degree, $49.4 \%$ master level education while there were 27.85 respondents were with $\mathrm{PhD}$ degree. 
Table 1

Demographic Profile of the Respondents

\begin{tabular}{lll}
\hline Demographic Characteristics & Frequency & Percentage (\%) \\
\hline Gender & 262 & 52.4 \\
Male & 238 & 47.6 \\
Female & & \\
\hline Age & 170 & 34.0 \\
Less than 20 years & 182 & 36.4 \\
21-30 years & 96 & 19.2 \\
31-40 years & 52 & 10.4 \\
41-50 & & \\
\hline Education & 15 & 3.0 \\
High School and Below & 41 & 8.2 \\
Diploma & 58 & 11.6 \\
Bachelor & 247 & 49.4 \\
Master & 139 & 27.8 \\
\hline PhD & & \\
\hline
\end{tabular}

\subsection{Measurement Model}

Partial Least Square (PLS) analysis technique was employed by using the SmartPLS3.0 software Ringle, Wende, and Becker (2015). In an effort to refine all structural equation model two-stage analytical procedure was employed, where researcher tested the measurement model and structural model recommended by Hair Jr et al. (2014). Prior to structural modelling study has to assess the measurement model of latent construct for their dimensionality, validity, and reliability by going through the process named as confirmatory factor analysis (Rahi et al., 2017). The values of Cronbach's $(\alpha)$ and Composite Reliability were also tested as recommended by Henseler, Ringle, and Sinkovics (2009). Furthermore, two types of validity were examined, the first convergent validity and the second discriminant validity. Convergent validity of measurement model is usually ascertained by examining the factor loading, average variance extracted and compost reliability (Hair et al., 2010; Rahi, 2017). Figure 2 shows the results of factor loadings as recommended by Chin (1998) threshold level of 0.6. The convergent validity was achieved as all the factor loadings values were above than 0.6.

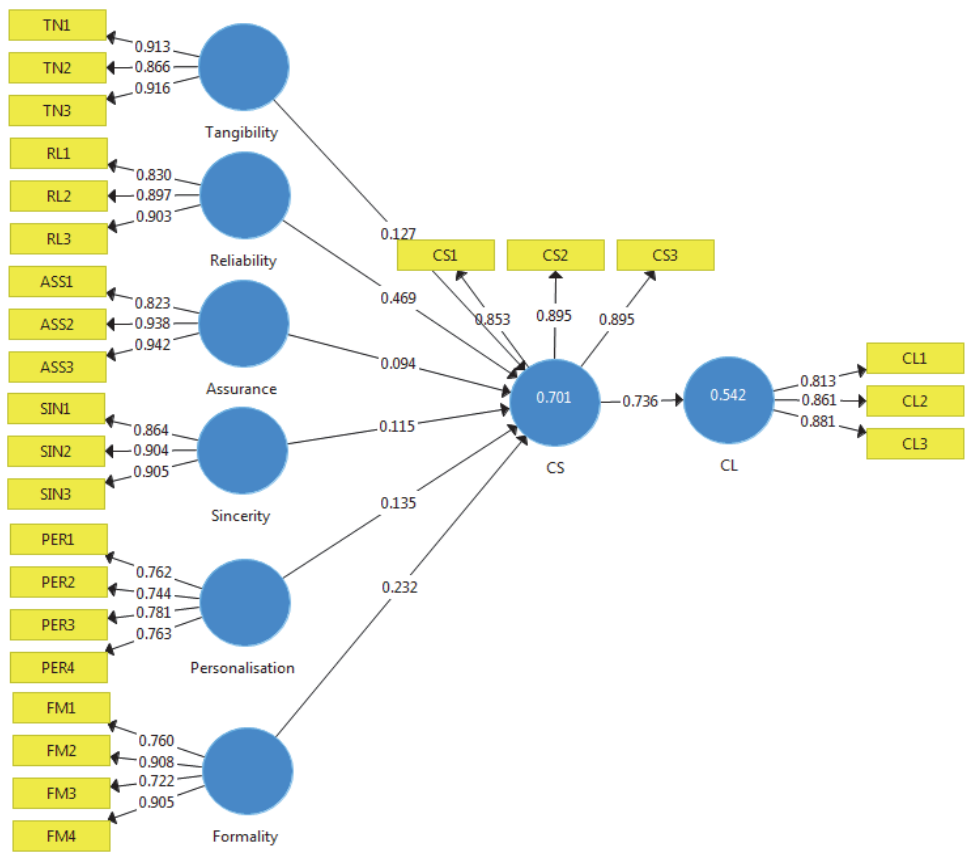

Fig. 2. Measurement Model 


\section{Convergent Validity}

Convergent validity of the measurement model is usually ascertained by examining the loading, average variance extracted and composite reliability (Rahi et al., 2017). Fornell and Larcker (1981) stated that average variance extracted (AVE) must be greater than 0.5. Furthermore, composite reliability (CR) degree where the construct indicator represent the latent construct, values exceeded 0.7 recommended by Hair et al. (2010). The values of average variance extracted (AVE), composite reliability (CR) and Cronbach's alpha $(\alpha)$ tabulated in Table 2.

\section{Table 2}

Results of Measurement Model

\begin{tabular}{|c|c|c|c|c|}
\hline Constructs & Loading & $(\alpha)$ & $\mathbf{C R}$ & AVE \\
\hline Assurance & ASS & 0.885 & 0.929 & 0.815 \\
\hline Islamic Banks offer financially safe investment & 0.823 & & & \\
\hline Employees of Islamic Banks are courteous & 0.938 & & & \\
\hline Employees of Islamic Banks have appropriate knowledge & 0.942 & & & \\
\hline Reliability & RL & 0.849 & 0.909 & 0.769 \\
\hline Employees of Islamic Banks fulfil their promises & 0.83 & & & \\
\hline Service specifications are followed by Islamic Banks & 0.897 & & & \\
\hline Islamic Banks deliver error-free services & 0.903 & & & \\
\hline Tangibility & $\mathbf{T N}$ & 0.882 & 0.926 & 0.808 \\
\hline The tools and equipment used by Islamic Banks are modern & 0.913 & & & \\
\hline The facilities offered by Islamic Banks are attractive & 0.866 & & & \\
\hline The communication material of Islamic Banks is easy to understand & 0.916 & & & \\
\hline Sincerity & SIN & 0.871 & 0.921 & 0.795 \\
\hline In Islamic Banks, customers' interest is taken from heart & 0.864 & & & \\
\hline Employees of Islamic Banks offer proactive advices & 0.904 & & & \\
\hline Employees of Islamic Banks are well mannered & 0.905 & & & \\
\hline Personalization & PER & 0.760 & 0.847 & 0.582 \\
\hline Individuals are given personal attention in Islamic Banks & 0.762 & & & \\
\hline In Islamic Banks, customers are called by their names & 0.744 & & & \\
\hline In Islamic Banks, there are customized solutions provided to customers' & 0.781 & & & \\
\hline In Islamic Banks immediate action is taken about any matter. & 0.763 & & & \\
\hline Formality & FM & 0.843 & 0.896 & 0.686 \\
\hline Employees of Islamic Banks do not use foul language & 0.76 & & & \\
\hline Employees of Islamic Banks pay full attention to customers & 0.908 & & & \\
\hline Employees of Islamic Banks are not friendly with customers. & 0.722 & & & \\
\hline Address customers by their family name whenever possible. & 0.905 & & & \\
\hline Customer Satisfaction & CS & 0.856 & 0.913 & 0.777 \\
\hline Assuming your entire experience with the Islamic Banks, you are satisfied & 0.853 & & & \\
\hline In general, your satisfaction level related to current Islamic Bank that you & 0.895 & & & \\
\hline The Islamic Banks exceed your expectations in offering & 0.895 & & & \\
\hline Customer Loyalty & $\mathbf{C L}$ & 0.812 & 0.822 & 0.727 \\
\hline I would like to revisit my Islamic Bank that I have already dealt with & 0.813 & & & \\
\hline I recommend my family, friends and relatives to visit the Islamic Bank & 0.861 & & & \\
\hline I will spread positive word-of-mouth about my Islamic Bank and its high & 0.881 & & & \\
\hline
\end{tabular}

\section{Discriminant Validity}

Discriminant validity of the constructs was evaluated using two criteria; Fornell-Larcker and crossloadings criterion. Discriminant validity is the degree where items differentiate among constructs and measures distinct concepts Fornell and Larcker (1981). Table 3 shows the discriminant validity of the instruments was examined by following Fornell and Larcker (1981). The square root of the AVE as showed in bold values on the diagonals was greater than the corresponding row and column values that indicate discriminant validity of the constructs. 
Table 3

Discriminant validity of Measurement Model

\begin{tabular}{lllllllll}
\hline Constructs & Ass & CL & CS & FM & PER & RL & SIN & TN \\
\hline Assurance & $\mathbf{0 . 9 0 3}$ & & & & & & & \\
Customer Loyalty & 0.281 & $\mathbf{0 . 8 5 2}$ & & & & & \\
Customer Service & 0.366 & 0.736 & $\mathbf{0 . 8 8 1}$ & & & & \\
Formality & 0.289 & 0.654 & 0.646 & $\mathbf{0 . 8 2 8}$ & & & \\
Personalization & 0.11 & 0.39 & 0.375 & 0.264 & $\mathbf{0 . 7 6 3}$ & & \\
Reliability & 0.265 & 0.529 & 0.743 & 0.557 & 0.242 & $\mathbf{0 . 8 7 7}$ & \\
Sincerity & 0.323 & 0.44 & 0.543 & 0.418 & 0.261 & 0.449 & $\mathbf{0 . 8 9 2}$ & \\
Tangibility & 0.229 & 0.312 & 0.429 & 0.322 & 0.192 & 0.277 & 0.428 & $\mathbf{0 . 8 9 9}$ \\
\hline
\end{tabular}

\section{Cross Loading}

As mentioned above, discriminant validity of the constructs was evaluated using two criteria; FornellLarcker and cross-loadings criterion. Thus discriminant validity was measured by examining the cross loading of the indicators Hair Jr et al. (2016). Discriminant validity can be done by comparing an indicator's outer loadings on the associated constructs and it should be greater than all of its loading on the other constructs Rahi et al. (2017). All the items measuring a particular constructs loaded higher on that construct and loaded lower on the other constructs that confirms the discriminant validity of the constructs. Cross loadings of the constructs is tabulated in Table 4.

Table 4

Loading and Cross Loadings

\begin{tabular}{lllllllll}
\hline Items & ASS & CL & CS & FM & PER & RL & SIN & TN \\
\hline ASS1 & $\mathbf{0 . 8 2 3}$ & 0.293 & 0.287 & 0.259 & 0.112 & 0.215 & 0.264 & 0.139 \\
ASS2 & $\mathbf{0 . 9 3 8}$ & 0.239 & 0.348 & 0.253 & 0.111 & 0.237 & 0.308 & 0.234 \\
ASS3 & $\mathbf{0 . 9 4 2}$ & 0.238 & 0.353 & 0.272 & 0.079 & 0.264 & 0.302 & 0.236 \\
CL1 & 0.235 & $\mathbf{0 . 8 1 3}$ & 0.556 & 0.484 & 0.315 & 0.406 & 0.321 & 0.247 \\
CL2 & 0.228 & $\mathbf{0 . 8 6 1}$ & 0.626 & 0.586 & 0.369 & 0.479 & 0.386 & 0.282 \\
CL3 & 0.254 & $\mathbf{0 . 8 8 1}$ & 0.69 & 0.595 & 0.316 & 0.464 & 0.411 & 0.267 \\
CS1 & 0.277 & 0.736 & $\mathbf{0 . 8 5 3}$ & 0.667 & 0.32 & 0.614 & 0.444 & 0.311 \\
CS2 & 0.373 & 0.599 & $\mathbf{0 . 8 9 5}$ & 0.513 & 0.321 & 0.664 & 0.474 & 0.431 \\
CS3 & 0.321 & 0.602 & $\mathbf{0 . 8 9 5}$ & 0.518 & 0.35 & 0.687 & 0.518 & 0.395 \\
FM1 & 0.204 & 0.656 & 0.472 & $\mathbf{0 . 7 6 0}$ & 0.213 & 0.416 & 0.336 & 0.271 \\
FM2 & 0.242 & 0.56 & 0.556 & $\mathbf{0 . 9 0 8}$ & 0.231 & 0.476 & 0.341 & 0.228 \\
FM3 & 0.273 & 0.4 & 0.531 & $\mathbf{0 . 7 2 2}$ & 0.232 & 0.478 & 0.354 & 0.347 \\
FM4 & 0.233 & 0.561 & 0.568 & $\mathbf{0 . 9 0 5}$ & 0.199 & 0.468 & 0.353 & 0.227 \\
PER1 & 0.119 & 0.299 & 0.289 & 0.194 & $\mathbf{0 . 7 6 2}$ & 0.193 & 0.172 & 0.11 \\
PER2 & 0.129 & 0.325 & 0.267 & 0.242 & $\mathbf{0 . 7 4 4}$ & 0.149 & 0.22 & 0.102 \\
PER3 & 0.06 & 0.298 & 0.289 & 0.231 & $\mathbf{0 . 7 8 1}$ & 0.208 & 0.21 & 0.153 \\
PER4 & 0.034 & 0.272 & 0.298 & 0.145 & $\mathbf{0 . 7 6 3}$ & 0.184 & 0.196 & 0.214 \\
RL1 & 0.186 & 0.534 & 0.625 & 0.572 & 0.209 & $\mathbf{0 . 8 3 0}$ & 0.373 & 0.192 \\
RL2 & 0.264 & 0.417 & 0.651 & 0.45 & 0.183 & $\mathbf{0 . 8 9 7}$ & 0.372 & 0.278 \\
RL3 & 0.246 & 0.444 & 0.679 & 0.45 & 0.243 & $\mathbf{0 . 9 0 3}$ & 0.435 & 0.256 \\
SIN1 & 0.254 & 0.454 & 0.473 & 0.429 & 0.229 & 0.388 & $\mathbf{0 . 8 6 4}$ & 0.302 \\
SIN2 & 0.343 & 0.356 & 0.489 & 0.339 & 0.234 & 0.404 & $\mathbf{0 . 9 0 4}$ & 0.418 \\
SIN3 & 0.267 & 0.368 & 0.49 & 0.353 & 0.235 & 0.409 & $\mathbf{0 . 9 0 5}$ & 0.421 \\
TN1 & 0.202 & 0.257 & 0.342 & 0.265 & 0.164 & 0.193 & 0.384 & $\mathbf{0 . 9 1 3}$ \\
TN2 & 0.189 & 0.313 & 0.435 & 0.337 & 0.194 & 0.313 & 0.395 & $\mathbf{0 . 8 6 6}$ \\
TN3 & 0.227 & 0.26 & 0.363 & 0.254 & 0.153 & 0.222 & 0.369 & $\mathbf{0 . 9 1 6}$ \\
\hline & & & & & & & &
\end{tabular}

\subsection{Structural Equation Model}

Assessing the structural model involves evaluating $R^{2}$, beta and the corresponding $\mathrm{t}$-values. The hypothesis were tested by running a bootstrapping procedure, as suggested by F. Hair Jr et al. (2014). Thus, to obtain the t-values, a bootstrapping procedure with 1000 resamples was applied. The results of the proposed hypothesis are presented in Table 5. It can be seen that all seven hypotheses have significance relationship with their respective dependant variables. 
Table 5

Results of Structural Model Analysis (Hypothesis Testing)

\begin{tabular}{lllllll}
\hline Hypothesis & Relationship & B & SE & T Statistics & P Values & Results \\
\hline H1 & Tangibility $\rightarrow$ CS & 0.127 & 0.031 & 4.086 & 0.000 & Supported \\
H2 & Reliability $\rightarrow$ CS & 0.469 & 0.054 & 8.748 & 0.000 & Supported \\
H3 & Assurance $\rightarrow$ CS & 0.094 & 0.034 & 2.768 & 0.003 & Supported \\
H4 & Sincerity $\rightarrow$ CS & 0.115 & 0.041 & 2.826 & 0.002 & Supported \\
H5 & Personalisation $\rightarrow$ CS & 0.135 & 0.037 & 3.700 & 0.000 & Supported \\
H6 & Formality $\rightarrow$ CS & 0.232 & 0.057 & 4.055 & 0.000 & Supported \\
H7 & CS $\rightarrow$ CL & 0.736 & 0.029 & 25.771 & 0.000 & Supported \\
\hline
\end{tabular}

Table 5 showed that the relationship between tangibility to customer satisfaction is supported by $\mathrm{H} 1$ : $(\beta=0.127, t=4.086, p<0.000)$.Next to this the relationship between reliability to customer satisfaction is significant by $\mathrm{H} 2$ : $(\beta=0.469, \mathrm{t}=8.748, \mathrm{p}<0.000)$. H3 showed that assurance is positively related to customer satisfaction by $(\beta=0.094, t=2.768, p<0.003)$. Similarly, the relationship between sincerity to customer satisfaction is supported by $\mathrm{H} 4:(\beta=0.115, \mathrm{t}=2.826, \mathrm{p}<0.002)$. H5 showed that personalisation is positively related to customer satisfaction by $(\beta=0.135, \mathrm{t}=3.700, \mathrm{p}<0.000)$. Furthermore, H6 showed that formality is positively related to customer satisfaction by $(\beta=0.232, \mathrm{t}=$ $4.055, \mathrm{p}<0.000)$. Finally, the results of $\mathrm{H} 7$ where customer satisfaction is supported to customer loyalty by $(\beta=0.736, t=25.771 \mathrm{p}<0.000)$. Thus, all hypotheses are significant. Furthermore, the effect size was also measured with $R^{2}$. The $R^{2}$ for customer satisfaction was 0.701 and for customer loyalty 0.542 , which is acceptable based on the cut-off suggested by (Cohen, 1988).

\section{Discussion}

The core objective of this study was to test the PAKSERV model in Islamic Banks of Palestine. The results of this study revealed that all hypothesis proposed in research model were supported. The six dimensions of PAKSERV model have been proved significant contribution towards customer satisfaction. Furthermore, the relationship between customer satisfaction and customer loyalty was also significant that add strength in the model. The dimensions of reliability $(0.469)$ and formality $(0.232)$ highly contributed towards customer satisfaction. Raajpoot (2004) explained that tangibility, reliability and assurance were the most important dimension of SERVQUAL model. In line with previous study by Raajoppt (2004) this study also confirms that the dimensions of PAKSERV; reliability and formality are the most important service quality dimension in Islamic banks of Palestine. Furthermore, the results of PAKSERV model is also in line with Graham Saunders (2008).

\section{Conclusion}

The rapid growth in services sector in Palestine made it important to understand and measure the service quality in Islamic Banks. Therefore, this paper has used PAKSERV model to identify the service quality in cultural perspective. Data were collected form Islamic Bank of Palestine and findings revealed that PAKSERV model is best fitted to measure service quality in Palestini Islamic Banks. Furthermore, study revealed that reliability was the most important dimension of PAKSERV model in Arab service quality context. Findings of this study was also in line with (Graham Saunders, 2008). The proposed PAKSERV model provides guideline for service managers to develop an appropriate service strategy by recognising the importance of benevolence and respect in their delivery of services.

\subsection{Limitation and Future Research}

Despite the methodological contribution, this study has some limitations. First, the sampled data was represented only one bank of Palestine. Second, PAKSERV model was tested in high-contact services setting i.e. banking that could limited its generalizability in other services sector. Thus, future researcher may replicate PAKSERV model in public sector such as healthcare, food, and telecom. 


\section{References}

Amin, M., Isa, Z., \& Fontaine, R. (2013). Islamic banks: Contrasting the drivers of customer satisfaction on image, trust, and loyalty of Muslim and non-Muslim customers in Malaysia. International Journal of Bank Marketing, 31(2), 79-97.

Ashforth, B. E., \& Humphrey, R. H. (1993). Emotional labor in service roles: The influence of identity. Academy of management review, 18(1), 88-115.

Avkiran, N. K. (1999). Quality customer service demands human contact. International Journal of Bank Marketing, 17(2), 61-74.

Bahia, K., \& Nantel, J. (2000). A reliable and valid measurement scale for the perceived service quality of banks. International Journal of Bank Marketing, 18(2), 84-91.

Baumann, C., Elliott, G., \& Hamin, H. (2011). Modelling customer loyalty in financial services: a hybrid of formative and reflective constructs. International Journal of Bank Marketing, 29(3), 247267.

Brown, S. W., \& Bitner, M. J. (2006). Mandating a services revolution for marketing. The ServiceDominant Logic of Marketing: Dialog, Debate, and Directions, 393-405.

Chin, W. W. (1998). Commentary: Issues and opinion on structural equation modeling: JSTOR.

Cohen, J. (1988). Statistical power analysis for the behavioural sciences. Hillside. NJ: Lawrence Earlbaum Associates.

East, R. (1997). Consumer behaviour: Advances and applications in marketing: Prentice Hall.

Fornell, C., \& Larcker, D. F. (1981). Structural equation models with unobservable variables and measurement error: Algebra and statistics. Journal of Marketing Research, 382-388.

Graham Saunders, S. (2008). Measuring and applying the PAKSERV service quality construct: Evidence from a South African cultural context. Managing Service Quality: An International Journal, 18(5), 442-456.

Hair, J. F. (2003). Essentials of Business Research Methods: Wiley.

Hair, J. F., Black, W. C., Babin, B. J., Anderson, R. E. \& Tatham, R. L. . (2010). Multivariate Data Analysis 7.

Hair Jr, J., Sarstedt, M., Hopkins, L., \& G. Kuppelwieser, V. (2014). Partial least squares structural equation modeling (PLS-SEM) An emerging tool in business research. European Business Review, 26(2), 106-121.

Hair Jr, J. F., Hult, G. T. M., Ringle, C., \& Sarstedt, M. (2016). A primer on partial least squares structural equation modeling (PLS-SEM): Sage Publications.

Henseler, J., Ringle, C. M., \& Sinkovics, R. R. (2009). The use of partial least squares path modeling in international marketing. Advances in international marketing, 20(1), 277-319.

Kamarulzaman, Y., \& Madun, A. (2013). Marketing Islamic banking products: Malaysian perspective. Business Strategy Series, 14(2/3), 60-66.

Kitapci, O., Taylan Dortyol, I., Yaman, Z., \& Gulmez, M. (2013). The paths from service quality dimensions to customer loyalty: An application on supermarket customers. Management Research Review, 36(3), 239-255.

Laroche, M., Ueltschy, L. C., Abe, S., Cleveland, M., \& Yannopoulos, P. P. (2004). Service quality perceptions and customer satisfaction: evaluating the role of culture. Journal of International Marketing, 12(3), 58-85.

Malhotra, N. K., Ulgado, F. M., Agarwal, J., Shainesh, G., \& Wu, L. (2005). Dimensions of service quality in developed and developing economies: multi-country cross-cultural comparisons. International marketing review, 22(3), 256-278.

Marković, S., Jelena, D., \& Katušić, G. (2015). Service Quality Measurement in Croatian Banking Sector: Application of SERVQUAL Model. Paper presented at the MIC 2015: Managing Sustainable Growth.

Oliver, R. L. (1980). A cognitive model of the antecedents and consequences of satisfaction decisions. Journal of Marketing Research, 460-469.

Oliver, R. L. (1997). Loyalty and profit: Long-term effects of satisfaction. 
Parasuraman, Zeithaml, V. A., \& Berry, L. L. (1985). A conceptual model of service quality and its implications for future research. the Journal of Marketing, 41-50.

Raajpoot, N. (2004). Reconceptualizing service encounter quality in a non-western context. Journal of Service Research, 7(2), 181-201.

Rahi, S. (2015). Moderating Role of Brand Image With Relation to Internet Banking and Customer Loyalty: A Case of Branchless Banking. The Journal of Internet Banking and Commerce, 2015.

Rahi, S. (2016). Impact of Customer Perceived Value and Customer's Perception of Public Relation on Customer Loyalty with Moderating Role of Brand Image. Journal of Internet Banking and Commerce, 21(2).

Rahi, S. (2016). Impact of Customer Value, Public Relations Perception and Brand Image on Customer Loyalty in Services Sector of Pakistan. Arabian J Bus Manag Review S, 2, 2.

Rahi, S. (2017). Research Design and Methods: A Systematic Review of Research Paradigms, Sampling Issues and Instruments Development. International Journal of Economics \& Management Sciences, 6(2).

Rahi, S., \& Ghani, M. (2016). Internet Banking, Customer Perceived Value and Loyalty: The Role of Switching Costs. J Account Mark, 5(188), 2.

Rahi, S., \& Ghani, M. A. (2016). Customer's perception of public relation in e-commerce and its impact on e-loyalty with brand image and switching cost. Journal of Internet Banking and Commerce, 21(3).

Rahi, S., Yasin, N. M., \& Aanaser, F. M. (2017). Measuring the role of website design, assurance, customer service and brand image towards customer loyalty and intention to adopt interent banking. The Journal of Internet Banking and Commerce, 22(S8).

Rahi, S., Ghani, M.A., \& Alnaser, F. M.-I.-. (2017). The influence of e-customer services and preseived value on brand quality of banks and internet banking adoption: A structural equation model (SEM). Journal of Internet Banking and Commerce, 22(1).

Ringle, C. M., Wende, S., \& Becker, J.-M. (2015). SmartPLS 3. Boenningstedt: SmartPLS GmbH.

Sayani, H. (2015). Customer satisfaction and loyalty in the United Arab Emirates banking industry. International Journal of Bank Marketing, 33(3), 351-375.

Taylor, S. A., \& Baker, T. L. (1994). An assessment of the relationship between service quality and customer satisfaction in the formation of consumers' purchase intentions. Journal of retailing, 70(2), $163-178$

Vanparia, B., \& Patel, V. (2013). Typology of Service Quality Model of Bank Services: BSQ v/s BANKQUAL. Global Journal of Research in Management, 3(1), 71.

Zeithaml, V. A., Berry, L. L., \& Parasuraman, A. (1996). The behavioral consequences of service quality. the Journal of Marketing, 31-46.

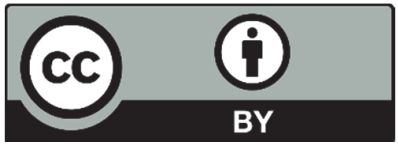

(C) 2017 by the authors; licensee Growing Science, Canada. This is an open access article distributed under the terms and conditions of the Creative Commons Attribution (CC-BY) license (http://creativecommons.org/licenses/by/4.0/). 